\title{
Profile of 3 Years and 4 Years Vocational School Relationship With The Preparation of Graduates Building Engineering Expertise Program
}

\author{
Sheila Ayu Pratama ${ }^{1, a^{*}, \text { E. Titiek Winanti2,b, Arie Wardhono } 2, c}$ \\ ${ }^{1}$ Department of Technology and Vocational Education, Universitas Negeri Surabaya, Surabaya, Indonesia \\ 2 Department of Civil Engineering, Universitas Negeri Surabaya, Surabaya, Indonesia \\ a sheilapratama16070895031@mhs.unesa.ac.id, btitiekwinanti@unesa.ac.id , c ariewardhono@unesa.ac.id \\ ${ }^{*}$ Corresponding Author \\ Whatsapp number: [+62-8191796 9169]
}

How to Cite : Pratama, S., A., Winanti, E., T., Wardhono, A. (2019). Profile of 3 Years and 4 Years Vocational School Relationship With The Preparation of Graduates Building Engineering Expertise Program. International Journal for Educational and Vocational Studies, 1 (6), 623-626

\section{ARTICLE HISTORY}

Received: 3 July 2019

Revised: 27 July 2019

Accepted: 7 September 2019

\section{KEYWORDS}

3-year Vocational School; 4-year Vocational School;

Building Engineering Expertise Program;

\begin{abstract}
This study aims to determine differences (1) curriculum structure; (2) industrial work practices; (3) graduate work readiness; and (4) the absorption of graduates between 3-year Vocational Schools and 4-year Vocational School building engineering expertise programs. The research method used was descriptive research with ex post facto approach and survey. Data collection techniques in this study used documentation, interviews and online questionnaires. The results of this study are as follows: (1) the learning burden on 3-year Vocational High Schools is $5016 \mathrm{JP}$ and $413 \mathrm{KD}$ while the 4-year Vocational School is $6648 \mathrm{JP}$ and $443 \mathrm{KD}$; (2) apprenticeship implemented at 3 Years Vocational School for 3 months and 4 Year Vocational School for 6-8 months; (3) 3-year SMK graduates $60 \%$ of whom are declared ready for work, while 4 -year SMK graduates $71.80 \%$ of whom are declared more ready to work; and (4) $70 \%$ of 3-year vocational school graduates work in a field, while $92 \%$ of 4-year SMK graduates work in a field. This can explain that it will be more effective if the Vocational School is held with a 4-year SMK pattern.
\end{abstract}

This is an open access article under the CC-BY-SA license.

\section{INTRODUCTION}

Indonesia as a developing country to become a developed country, it is important to make its population as quality human resources (HR) in terms of economy and education. Education is the right tool to equip people in terms of attitudes, skills, science and technology, and culture. According to Good News From Indonesia (2017), the World Economic Forum (WEF) reported by the Global Human Capital Report which examines the quality of Human Resources (HR) in 130 countries, Indonesia ranked 65th.

One of the levels of education in Indonesia that is expected in an effort to improve the quality of its human resources is the Vocational High School (SMK). This is because Vocational Schools are middle-level educational institutions that aim to produce graduates who have competencies in accordance with what is needed in the world of work. The success of Vocational Schools in education can not only be measured by the number of students who graduate or achievers but from how many graduates can be absorbed in the world of work and also graduates who have good quality and quantity in the workplace.

Based on the Indonesian Central Bureau of Statistics (BPS) (2018), it states that the number of unemployed people in Indonesia is $8.92 \%$ for SMKs; $2.67 \%$ for elementary school; $5.18 \%$ for SMP; $6.31 \%$ for the University; $7.19 \%$ for SMA and $7.92 \%$ for Diploma. However, the unemployment rate according to education is still high in vocational majors and this is a duty for the government about how the vocational curriculum can answer the world of work.

The development of the curriculum in Indonesia has been based on current developments. In 2018, the curriculum used in various levels of school education is the 2013 curriculum. The development of this curriculum is expected to improve the quality of Indonesian human 
resources in the field of education. Therefore, President Jokowi issued presidential instruction no. 9 of 2016 concerning revitalization of SMK. This program aims to boost the quality of Indonesian human resources by strengthening the relationship between SMK and the world of work and boosting local excellence into global excellence.

Now there are two SMK models in Indonesia, namely 4-year SMKs with 4 years of education and 3 years of SMKs with 3 years of education. This old difference in education can affect the quality of the individual. In line with the research of Lesmana (2016), it is explained that the quality possessed by SMK graduates must be in line with the quality of graduates needed by the workforce, so that vocational graduates can be optimally absorbed in the world of work.

To jump into the world of work there needs to be a well prepared readiness. This readiness must be instilled since implementing learning in Vocational Schools. This readiness can be a good mastery of skills (expertise) in accordance with their fields and have a good attitude. Thus, if someone has a good work readiness, it will have a good effect when they enter the workforce.

In accordance with Dirwanto's (2008) research, finding that work readiness is influenced by several factors, namely: (1) ability factor; (2) self-image factors; (3) supporting factors, which consist of employment information, family economic conditions and vocational guidance; (4) academic factors; (5) basic / standard factors, consisting of values, physical condition and talent; (6) behavioral factors; and (7) aspirational and potential factors. The factor which gives the biggest contribution lies in the ability factor namely skills, practical experience and creativity. Based on the description above, if someone has some of the above factors well, then that person has good work readiness.

The research of Soenarto et al (2017), which examined the work readiness of 3-year SMK graduates and 4-year SMK graduates. The study found the results that the employability of a 4-year program graduate was better than the 3-year program and this was influenced by vocational high school policy. In this study, researchers conducted studies in all areas of expertise that are summarized into one while in this study, focusing more on one expertise program that is Building Engineering

In this research, it will not only discuss work readiness and some aspects underlying it such as the curriculum structure used and industry work experience, but also discuss the absorptive capacity of 3-year SMK graduates and 4-year SMK in the world of work. Because more and more graduates are absorbed in the world of work, it shows that graduates have good job readiness.

\section{METHODS}

The research method used in this study is descriptive research with ex post facto approach and survey. The population in this study were 3-year Vocational High
School graduates and 4-year Vocational High Schools who received 2013 Curriculum learning. Samples are randomly assigned via tracer study. Data was collected by the method of documentation, interviews and online questionnaires.

\section{RESULTS AND DISCUSSIONS}

\subsection{Curriculum Structure}

There is a difference in curriculum structure used by 3-year Vocational Schools and 4-year Vocational High Schools. The curriculum used by the 3-year vocational school refers to the competency of building design and information design skills (DPIB) while the vocational school is 4 years in the competence of building construction, sanitation and maintenance (KGSP) expertise. Other differences are in subjects, basic competencies (KD) along with the learning burden taken. In the 2013 curriculum, 3-year Vocational Schools have 19 subjects with a total learning load of $5016 \mathrm{JP}$ and $413 \mathrm{KD}$, while 4-year Vocational Schools have 20 subjects with a total learning load of $6648 \mathrm{JP}$ and $443 \mathrm{KD}$. Thus, the insights obtained by 4-year Vocational High Schools are more than 3-year Vocational Schools and this encourages students to have better work readiness.

\subsection{Industrial Work Practices}

There is a difference in duration of the implementation of industrial work practices in 3-year Vocational Schools different from 4-year Vocational High Schools. The 3-year Vocational School implements internship for 3 months during class XI, while 4-year Vocational Schools hold internship for 6-8 months during class XIII after implementing the National Examination. The longer and a lot of knowledge is learned, the better the quality of students is honed.

\subsection{Graduate Work Readiness}

Of the several factors above, if it goes well, the readiness of work to be obtained will also work well. The following is an illustration of the percentage of work readiness of 3-year Vocational High School graduates and 4-year Vocational High Schools.

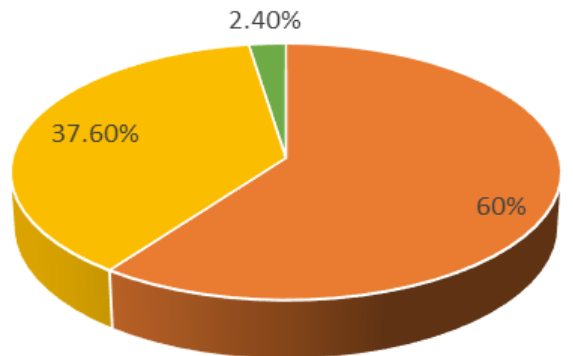

Figure 1. Percentage of Work Readiness for Graduates in 3 Years Vocational School. 
Based on Figure Diagram 1 above, it can be seen that $60 \%$ of graduates have good work readiness, which means the willingness to work and mastery in the job is quite good.

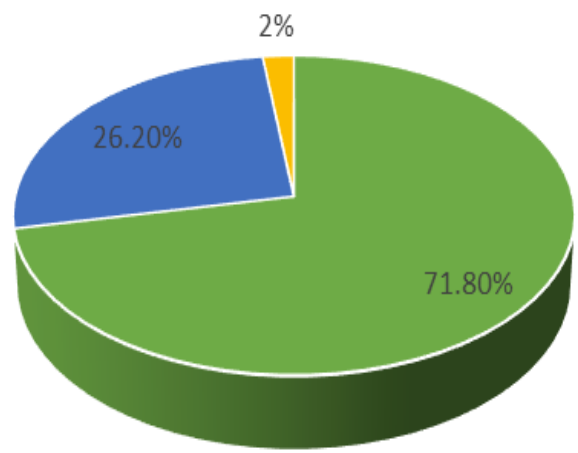

Figure 2. Percentage of Work Readiness for Graduates in 4 Years Vocational School.

Based on Figure Diagram 2 above, it can be seen that $71.80 \%$ of graduates including having good work readiness means the willingness to work and mastery in good work. So it can be seen that the work readiness of 4-year Vocational Schools has a greater percentage than the 3-year Vocational School.

\subsection{Absorption of Graduates}

The absorption of graduates in DU/DI for 4-year Vocational Schools is more than 3-year Vocational High Schools. This fact has been proven by the above, starting from the large number of DU/DI that employ 4 years of vocational school graduates and the number of job positions given and projects undertaken. Below will be illustrated a diagram showing the absorption of 3-year Vocational School graduates and 4-year Vocational Schools based on their suitability with vocational competencies.

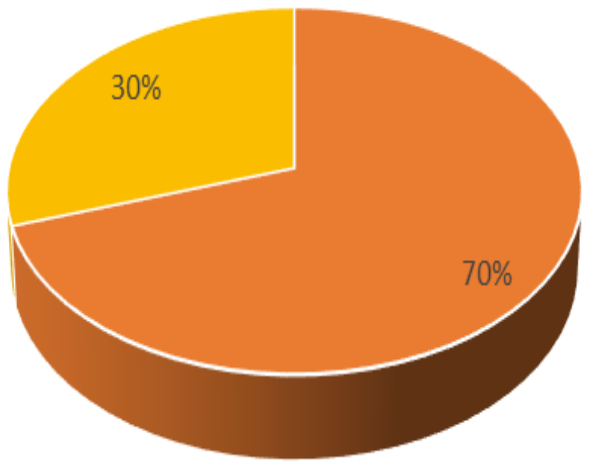

Figure 3. Absorption Results of Graduates According to Vocational Skills Competencies of 3 Years

Based on Figure 3 above, it shows that $70 \%$ of graduates work according to their fields of expertise and $30 \%$ of graduates work but are not in accordance with their fields of expertise in Vocational High Schools.

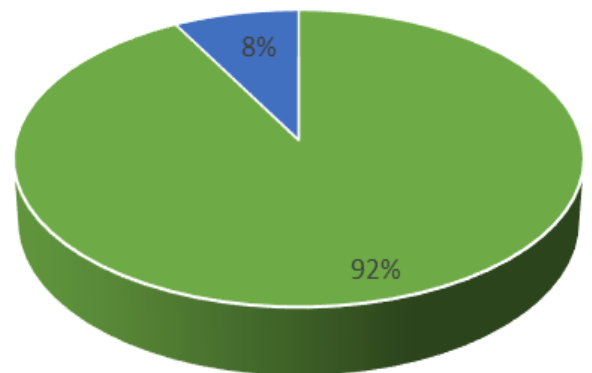

Figure 4. Absorption Results of Graduates in 4 Years Vocational Skills Competence

Based on Figure 4 above, it shows that $92 \%$ of graduates work according to their fields of expertise, $8 \%$ of graduates work but are not in accordance with their fields of expertise. So it can be seen that the absorption of 4-year vocational school graduates is greater than 3-year vocational school graduates.

\section{CONCLUSION}

Based on the description above, it can be concluded that there are differences: (1) curriculum structure; (2) apprenticeship; (3) work readiness; (4) the absorption of graduates between 3-year Vocational High Schools and 4-year Vocational High Schools. Thus, the quality of good work depends on the provision of work readiness received at school. Good work readiness is motivated by several aspects such as experience when doing industrial work practices and curricula that are used as learning references. The more graduates absorbed in the workforce, the more graduates have good work readiness.

\section{REFERENCES}

Depdiknas. (2003). Undang-undang RI No. 20 tahun 2003 tentang sistem pendidikan nasional.

Dirwanto. (2008). Analisis faktor-faktor yang mempengaruhi kesiapan kerja pada siswa SMK Ma'arif NU Kesesi Kabupaten Pekalongan Tahun Pelajaran 2007/2008. (Tesis tidak dipublikasikan), Universitas Sebelas Maret, Surakarta.

Kusuma, H., (2018, Januari 3). Cita-cita Jokowi di 2018: meningkatkan kualitas SDM RI [web log post]. Retrieved from https://finance.detik.com

Lesmana, W., (2016). Keselarasan kualitas/kompetensi lulusan SMK jurusan teknik gambar bangunan di kota Yogyakarta dengan dunia kerja, 1-7. Diunduh dari journal.student.uny.ac.id

Ramadhan, B., (2017, September 14). World economic forum lansir peringkat kualitas SDM dunia, ini peringkat Indonesia [web log post]. Retrieved from https://www.goodnewsfromindonesia.id

Ramadhan, B. (2018, Mei 7). Pengangguran RI 6,87 juta orang, paling banyak lulusan SMK [web log post]. 
Retrieved from https://finance.detik.com

Soenarto dkk. (2017). Evaluasi implementasi kebijakan sekolah menengah kejuruan program 4 tahun dalam meningkatkan employability lulusan. Jurnal penelitian dan evaluasi pendidikan, Jurnal Penelitian dan Evaluasi Pendidikan, 21(2), 215-227.

Diunduh darihttp://journal.uny.ac.id/index.php/jpep. 